\title{
Organic seeds storage: A case study with lettuce and salad rocket
}

\author{
Almacenamiento de semillas orgánicas: Caso de estudio con lechuga y rúcula
}

Ariel Santivañez Aguilar ${ }^{1}$, Vanderley José Pereira²*, Diego Tolentino de Lima²

\begin{abstract}
The objective of this study was to evaluate the germination process of lettuce (Lactuca sativa L.) and salad rocket (Eruca sativa L.) storead cypselae/seeds, both organic and conventional, to verify if one is more suited for seed production. The cypselae/seeds were stored in metal containers in a cold chamber. Then, they were placed inside Gerbox boxes in a Mangelsdorf germinator set at $20^{\circ} \mathrm{C}$, under continuous fluorescent white light. Germination capacity, time, rate, uniformity, and synchrony were then measured. The experimental design applied to lettuce was completely randomized with 2 varieties x 2 systems (organic, and conventional), with five repetitions of 25 seeds each. The design chosen for the salad rocket followed a similar rationale, with two systems (organic and conventional), comprised of ten repetitions of 25 seeds each. The assumptions were tested, followed by ANOVA, average tests, and charts as functions of time. Lettuce cypselae withstood storage for ten years, maintaining their viability and germination pattern over time. The cypselae in the conventionally-grown Rainha de Maio cultivar were more suitable, while for the Quatro Estações cultivar, the organically-grown ones which were proved to be more suitable. Both conventional and organic salad rocket seeds remained viable for more than nine years. The conventional seeds were faster, more uniform, and presented a greater synchronization index, nevertheless.
\end{abstract}

Keywords: Eruca sativa L.; Lactuca sativa L.; viability of seeds; cropping systems; aging of seeds.

\section{RESUMEN}

El objetivo del estudio evaluó el proceso germinativo de cipselas/semillas almacenadas de lechuga y rúcula de sistemas orgánicos y convencionales. El almacenamiento fue en envases de metal dentro de cámara fría, fueron acondicionadas en cajas Gerbox, en germinador Mangelsdorf $a 20{ }^{\circ} \mathrm{C}$, bajo luz blanca fluorescente continua. Se calcularon medidas de capacidad, tiempo, velocidad, uniformidad y sincronización. El delineamiento para lechuga fue completamente casualizado con 2 cultivares $x 2$ sistemas (orgánico y convencional), con cinco repeticiones de 25 semillas. Para rúcula el delineamiento fue el mismo con dos sistemas (orgánico y convencional), con diez repeticiones de 25 semillas. Se probaron las presuposiciones, seguido del análisis de varianza, comparación de medias y gráficos en función al tiempo. Las cipcelas de lechuga toleran el almacenamiento durante diez años, manteniendo la viabilidad y el patrón de germinación a lo largo del tiempo. Sin embargo, la respuesta es particular por genotipo, las cipcelas de la cv. Rainha de Maio convencionales son más aptas, mientras que para la cv. Quatro Estações las orgánicas se muestran viables. Las semillas de rúcula permanecen viables por más de nueve años, pero las semillas convencionales son más rápidas, uniformes y presentan mayor sincronía.

Palabras clave: Eruca sativa L., Lactuca sativa L., viabilidad de las semillas, sistemas de cultivo, envejecimiento de las semillas.

\section{Introduction}

Organic products go through a mandatory review by the Ministry of Agriculture, Livestock and Food supply of Brazil (Ministério da Agricultura Pecuária e Abastecimento - MAPA) and must adhere to legislation that advocates the use of organic seeds (Mapa, 2011; Mapa, 2013). However, there is no incentive to produce organic seeds, which, together with the sector regulation, entails production difficulties (Dias et al., 2015). This organic seed shortage is due to the lack of interest from large companies, which would be required to change the entire cultivation system, and the lack of research in production, maintenance, and seed quality evaluation. This leads to the importation of organic seeds (Nascimento et al., 2012) or the use of conventional seeds for seedling production aimed at

\footnotetext{
1 Universidade Estadual Paulista Júlio de Mesquita Filho. São Paulo, SP, Brazil.

2 Universidade Federal de Uberlândia. Uberlândia, MG, Brazil.

* Corresponding author: vamceres.vanderley@gmail.com
}

Fecha de Recepción: 20 de marzo, 2020.

Fecha de Aceptación: 8 de septiembre, 2020. 
the organic market (Dias et al., 2015). Furthermore, there is little research on seed storage of organic vegetables, most of which relies on generic data.

It is known that the ability of a seed to maintain its quality over time relies on the storage conditions, the cultivar's inherent longevity, as well as the initial quality, inherent to the management used. There are also studies, that conclude that the effect of plant nutrition on seed quality can be observed only after a period in storage (Zucareli et al., 2006). For vegetables, such as lettuce and salad rocket, which are species that exhibit slow nutrient absorption during the first half of the cultivation cycle, which accelerates close to harvest, organic management may influence the quality of the seeds. This is because at the beginning of the reproductive phase, nutrient requirements increase and become critical during the formation of seeds when a considerable amount of nutrients is reallocated (Cardoso et al., 2011). Thus, the use of organic fertilizers is more recommended since the release of mineral nutrients is slower because they depend on the mineralization of organic matter, which is released throughout the cycle of the plant. Although the lack of scientific information has not impeded the production of organic seeds, their production relies on inferences drawn from conventional farming. Such findings can be ratified by the fact that these seeds are marketed in Brazil even though there are no studies aimed at organically-grown Salad rocket (Eruca sativa $\mathrm{L}$ ) and lettuce (Lactuca sativa $\mathrm{L}$ ) seeds/ cypselae. Thus, the objective of this study was to evaluate the germination pattern of stored lettuce and salad rocket seeds/cypselae grown in organic and conventional systems to verify if one is more suited for seed production.

\section{Material And Methods}

Initially, untreated salad rocket seeds from commercial lots of rocket salad of cultivar Cultivada (Eruca sativa L., family: Brassicaceae) cultivated in organic and conventional systems yielded 1.67 and $1.55 \mathrm{~g}$ mass in a thousand seeds, and $100 \%$ (analysis on 11/2003) and 94\% (analysis on 11/2006) germination, respectively. The cypselae from untreated commercial lots of lettuce cultivar Quatro Estações and Rainha de Maio (Lactuca sativa L., family: Asteraceae) cultivated in organic and conventional systems yielded 0.98, 1.05, 0.87 and $1.13 \mathrm{~g}$ mass in a thousand cypselae and $91 \%$
(10/2006 analysis), 93\% (analysis on 09/2006), 96\% (analysis on 07/2005) and 93\% (analysis on 05/2005) germination respectively. Immediately after the analysis, the seeds and cypselae were placed in metal containers in a cold chamber under controlled conditions at a temperature of $10^{\circ} \mathrm{C}$ with a relative air humidity of $30 \%$ until October 2015, when the experiment was conducted. After storage, seeds, and cypselae were placed in Gerbox plastic boxes, which were lined with two sheets of blotting paper. These sheets had been previously moistened with distilled water at an amount equivalent to 2.5 times the weight of the paper. The Gerbox boxes were kept in a Mangelsdorf germinator at $20{ }^{\circ} \mathrm{C}$ under continuous fluorescent white light (Brasil, 2009). The humidity of the paper throughout the study was maintained constant.

The germination counts were carried out daily; germinated seeds were removed, according to the protrusion of the embryo (radicle with geotropic curvature or photosynthetic cotyledons). Germination was counted until the end of the process. With the collected data, we were able to calculate the germinability, as well as the first, last, and mean germination time; coefficient of variation of the germination time, which measures the dispersion around the average; the mean germination rate; rate of Maguire, which combines time and germination; the uncertainty and the synchronization index of the germination (Table 1). To study the distribution over time, we relied on the Relative frequency of germination graphs for all treatments (Table 1). For more information about these measurements, see Ranal \& Santana (2006), where these expressions were presented for the first time, their intermediate calculation, sense, and applications.

For the lettuce cypselae, treatments followed a factorial scheme composed of 2 varieties of lettuce (Quatro Estações and Rainha de Maio) x 2 cultivation systems (organic and conventional). They were arranged in five replicates of 25 seeds each, following a completely randomized design. The outlining used in salad rocket was similar, with two treatments in organic and conventional cultivation systems, with ten replicates of 25 seeds each. The Shapiro Wilk test was applied for normality of residuals from ANOVA as well as Levine's for the homogeneity in the variances, at 0.01 significance. In the instances in which the data did not meet these two parametric statistics assumptions, the data at hand was transformed, and the assumptions were retested 
Table 1. Germination measurements and equations.

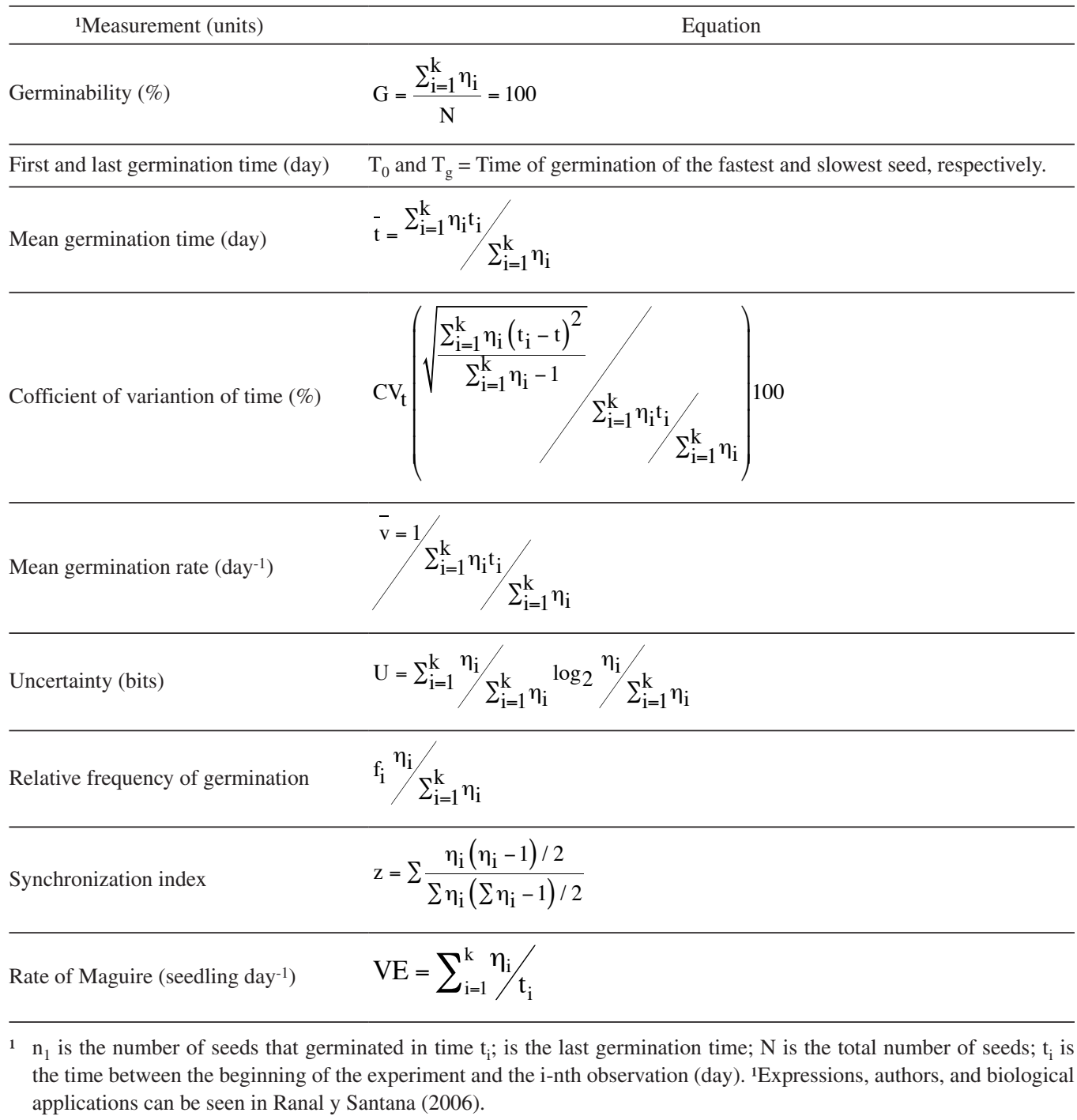

When both assumptions were met, variance analysis was then applied to the data, followed by Tukey's test for average comparison at 0.05 significance. When the degree of freedom of the residues was lower than ten and the number of observations of the experiment fewer than $20(n<20)$, Student's " $t$ " test was deployed on independent samples at 0.05 significance, then the normality assumptions for the residue of the individualized samples were tested as well as homogeneity of variances in a two by two fashion, at 0.01 significance. Sigmoidal and exponential regression models were adjusted to represent the accumulated germination over time to detect differences that may have gone undetected by one-off measurements in the germination process, out of which we selected those with good fit and were significant $\left(R^{2}\right)$.

\section{Results and Discussion}

Seeds and cypselae from both organically and conventionally-grown untreated commercial lots of Cultivada salad rocket as well as Rainha de Maio lettuce remained viable for a period longer than nine years (Tables 2 and 3). The Quatro Estações lettuce cypselae just proved viable in the organic system, whereas the conventionally-grown cypselae lost their viability completely (Table 2). For Rainha 
Table 2. Cypselae germination measurements of lettuce varieties (Lactuca sativa L.) grown in conventional and organic systems after storage.

\begin{tabular}{|c|c|c|c|c|}
\hline \multirow{2}{*}{ Lettuce cultivar ${ }^{1}$} & \multicolumn{2}{|c|}{ Germinability (\%) } & \multicolumn{2}{|c|}{ Mean germination time (day) } \\
\hline & Organic & z Conventional & Organic & Conventional \\
\hline Rainha de Maio & $\begin{array}{c}11.2 \pm 5.2 \mathrm{bA} \\
(-84.8)\end{array}$ & $\begin{array}{c}42.4 \pm 7.8 \mathrm{aA} \\
(-50.6)\end{array}$ & $6.4 \pm 3.0 \mathrm{aA}$ & $3.9 \pm 1.0 \mathrm{a}$ \\
\hline Quatro Estações & $\begin{array}{c}11.2 \pm 4.4 \mathrm{aA} \\
(-79.8)\end{array}$ & $\begin{array}{c}0.0 \pm 0.0 \mathrm{bB} \\
(-93.0)\end{array}$ & $5.5 \pm 2.1 \mathrm{~A}$ & - \\
\hline${ }^{2}$ Levene & $0.279^{\text {(rainha) }}$ & $1.796^{\text {(Org.) }}$ & $4.381^{\text {(rainha) }}$ & 0.469 (Org.) \\
\hline \multirow{2}{*}{ Lettuce cultivar } & \multicolumn{2}{|c|}{$\begin{array}{c}\text { Coefficient of variation of time } \\
(\%)\end{array}$} & \multicolumn{2}{|c|}{ First germination time (day) } \\
\hline & Organic & Conventional & Organic & Conventional \\
\hline Rainha de Maio & $94.1 \pm 23.1 \mathrm{bB}$ & $60.04 \pm 18.9 a$ & $1.8 \pm 0.8 \mathrm{aA}$ & $1.6 \pm 1.0 \mathrm{a}$ \\
\hline Quatro Estações & $40.4 \pm 23.0 \mathrm{~A}$ & - & $3.2 \pm 2.2 \mathrm{~A}$ & - \\
\hline${ }^{2}$ Levene & $0.709^{\text {(rainha) }}$ & $0.060^{\text {(Org.) }}$ & $0.640^{\text {(rainha) }}$ & $1.936^{\text {(Org.) }}$ \\
\hline \multirow{2}{*}{ Lettuce cultivar } & \multicolumn{2}{|c|}{ Last germination time (day) } & \multicolumn{2}{|c|}{ Mean germination rate $\left(\mathrm{day}^{-1}\right)$} \\
\hline & Organic & Conventional & Organic & Conventional \\
\hline Rainha de Maio & $12.2 \pm 7.2 \mathrm{aA}$ & $9.0 \pm 5.6 \mathrm{a}$ & $0.19 \pm 01 \mathrm{aA}$ & $0.3 \pm 0.1 \mathrm{a}$ \\
\hline Quatro Estações & $7.0 \pm 2.5 \mathrm{~A}$ & - & $0.2 \pm 0.1 \mathrm{~A}$ & - \\
\hline${ }^{2}$ Levene & $0.730^{\text {(rainha) }}$ & $6.296^{\text {(Org.) }}$ & $1.241^{\text {(rainha) }}$ & $0.046^{\text {(Org.) }}$ \\
\hline \multirow{2}{*}{ Lettuce cultivar } & \multicolumn{2}{|c|}{ Synchronization index } & \multicolumn{2}{|c|}{ Uncertainty (bit) } \\
\hline & Organic & Conventional & Organic & Conventional \\
\hline Rainha de Maio & $0.0 \pm 0.0 \mathrm{bA}$ & $0.2 \pm 0.1 \mathrm{a}$ & $1.3 \pm 0.8 \mathrm{aA}$ & $2.0 \pm 0.2 \mathrm{a}$ \\
\hline Quatro Estações & $0.1 \pm 0.1 \mathrm{~A}$ & - & $1.2 \pm 0.3 \mathrm{~A}$ & - \\
\hline${ }^{2}$ Levene & $5.819^{\text {(rainha) }}$ & 74.667(Org.) & $7.296^{\text {(rainha) }}$ & $4.780^{(\mathrm{Org} .)}$ \\
\hline \multirow{2}{*}{ Lettuce cultivar } & \multicolumn{4}{|c|}{ Rate of Maguire (seedling day ${ }^{-1}$ ) } \\
\hline & \multicolumn{2}{|r|}{ Organic } & \multicolumn{2}{|c|}{ Conventional } \\
\hline Rainha de Maio & \multicolumn{2}{|r|}{$1.0 \pm 06 \mathrm{bA}$} & \multicolumn{2}{|c|}{$3.8 \pm 0.7 \mathrm{a}$} \\
\hline Quatro Estações & \multicolumn{2}{|r|}{$0.7 \pm 0.2 \mathrm{~A}$} & \multicolumn{2}{|c|}{-} \\
\hline${ }^{2}$ Levene & \multicolumn{2}{|r|}{$0.031^{\text {(rainha) }}$} & \multicolumn{2}{|c|}{ 4.137(Org.) } \\
\hline
\end{tabular}

${ }^{1}$ Means followed by distinct lowercase letters in the row, and upper case letters in the column differ from each other in the Student's t test for independent samples $(P<0.05) ;{ }^{2}$ Bold values indicate homoscedasticity $(P \geq 0.01)$, in the cases of heteroscedasticity, the comparison was made by correcting the degrees of freedom; (rainha); (Org.) Levene's test statistics for Rainha de Maio cultivar in the organic system compared to the conventional system and Levene's test statistics for Rainha de Maio compared to Quatro Estações cultivar in the organic system. Shapiro-Wilk's test statistics for each sample were omitted because they were not normally distributed. Values within the parentheses represent the decrease in relation to the initial germination.

de Maio lettuce, the conventional system produced cypselae which were more suitable for storage than those grown in the organic system, even with a loss in germinability at approximately $50 \%$. In the Quatro Estações cultivar, the opposite was observed, where the organic system enabled the cypselae to be stored for longer periods, as germinability was still at $12.2 \%$. Even though there was an $80 \%$ decrease, this percentage was higher than that of those seeds which were conventionally-grown (null germination). The organic system for both varieties resulted in germination of $11.2 \%$. 
Table 3. Stored seeds germination measurements of "Cultivada" salad rocket

(Eruca sativa L.) cultivated in organic and conventional systems.

\begin{tabular}{lcccc}
\hline${ }^{1}$ Germination measurement (unit) & Organic & Conventional & $\mathrm{F}(\mathrm{P})$ & $\mathrm{W}(\mathrm{P})$ \\
\hline Germinability (\%) & $77.20 \pm 2.70 \mathrm{a}$ & $76.80 \pm 3.68 \mathrm{a}$ & $1.29(0.724)$ & $0.808(0.001)$ \\
& $(-16,8)$ & $(-23.2)$ & & \\
Mean germination time (day) & $1.72 \pm 0.29 \mathrm{~b}$ & $1.12 \pm 0.16 \mathrm{a}$ & $3.907(0.064)$ & $0.955(0.457)$ \\
Coefficient of variation of time (\%) & $88,61 \pm 28,64 \mathrm{~b}$ & $26.23 \pm 30.66 \mathrm{a}$ & $1.24(0.281)$ & $0.859(0.007)$ \\
First germination time (day) & $1.00 \pm 0.00 \mathrm{a}$ & $1.00 \pm 0.00 \mathrm{a}$ & - & - \\
Last germination time (day) & $5.60 \pm 1.26 \mathrm{~b}$ & $2.30 \pm 1.57 \mathrm{a}$ & $1.113(0.305)$ & $0.889(0.026)$ \\
Mean germination rate (day $\left.{ }^{-1}\right)$ & $0.60 \pm 0.10 \mathrm{~b}$ & $0.90 \pm 0.12 \mathrm{a}$ & $1.293(0.270)$ & $0.906(0.054)$ \\
Rate of Maguire (seedling day $\left.{ }^{-1}\right)$ & $15.88 \pm 1.04 \mathrm{~b}$ & $18.37 \pm 1.42 \mathrm{a}$ & $0.779(0.389)$ & $0.956(0.471)$ \\
Uncertainty (bits) & $1.21 \pm 0.23 \mathrm{~b}$ & $0.34 \pm 0,42 \mathrm{a}$ & $1.531(0.232)$ & $0.887(0.024)$ \\
Synchrony index & $0.56 \pm 0.09 \mathrm{~b}$ & $0.87 \pm 0.17 \mathrm{a}$ & $3.372(0.083)$ & $0.870(0.012)$ \\
\hline
\end{tabular}

${ }^{1}$ Means followed by distinct letters differ from each other by the Tukey's test $(P<0.05)$. $W=$ Shapiro-Wilk's test statistics; $F=$ Levene's test statistics; $P=$ probability $(P \geq 0.01$ indicates homoscedasticity and residuals normally distributed $)$.

As none of the Quatro Estações lettuce cypselae germinated in the conventional cultivation system, we could not make inferences regarding the other germination measurements (Table 2). The lettuce cypselae germination was precocious, and it did not vary in the first, last, and mean germination times among the varieties within the organic system; nor between cultivation systems for the Rainha de Maio cultivar. In general, the germination process began approximately on the second day, ended on the tenth, and peaked on the fifth day. However, germination took place dispersedly $\left(\mathrm{CV}_{t} \geq 40 \%\right)$, especially for the Rainha de Maio cypselae in the organic system (Table 2). The germination process could be classified as polymodal, with five spreadout peaks, which justified the $94 \%$ variation around the mean germination time for the Rainha de Maio cypselae in the organic system. A single cypsela sprouted on the $21^{\text {st }}$ day after it had been sown, which made the Rainha de Maio's germination process in conventional systems more dispersed $\left(\mathrm{CV}_{t}=60.4 \%\right.$; Figure 1b) than that of the Quatro Estações in an organic system $\left(\mathrm{CV}_{t}=40.4 \%\right.$; Figure 1c), since both processes presented two distinct peaks.

The mean germination rate of the process did not change between the cultivars or cultivation systems, nor did the uncertainty (Table 2), even with the peculiarity of the process seen in the germination frequency (Figure 1). However, it did affect the rate of Maguire as well as the Synchronization index dramatically. The Rainha de Maio cypselae cultivated in the organic system was less synchronic and had a lower daily germination frequency than those grown in the conventional system. These were also less synchronic than the Quatro Estações

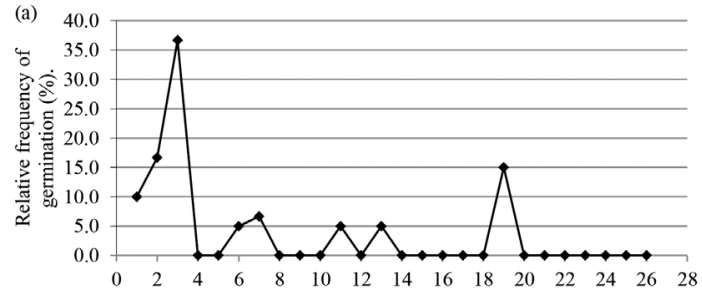

(b)
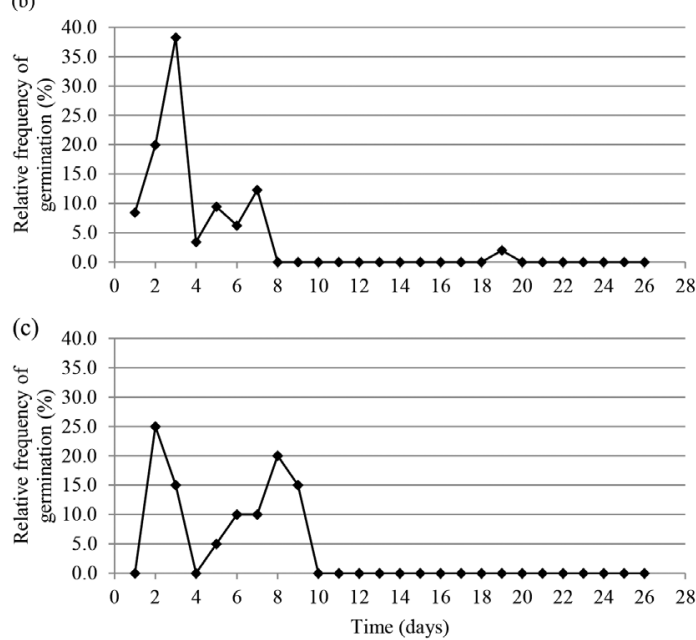

Figure 1. Relative frequency of cypselae germination of lettuce cultivars (Lactuca sativa L.) after storage. a) "Rainha de Maio" Lettuce cultivated in an organic system; b) "Rainha de Maio" Lettuce cultivated conventionally; c) "Quatro Estações" Lettuce cultivated in an organic system.

cultivar. They did not, however, differ regarding daily frequency (Table 2).

It was observed that considering the accumulated germination, regardless of the cultivar or cultivation system, the process grew exponentially with three parameters $\left(P \leq 0.05\right.$ and $\left.R^{2} \geq 93.65 \%\right)$. Two distinct 
phases were perceived, a fast initial one with large increments, which continued until the tenth day, and a subsequent stationary phase with low increments (Figure 2). The Rainha de Maio cultivar in the conventional system initially showed higher germination rates than all the others, and it remained so until the end of the experiment. Even though the process resulted in similar germination rates, the dynamics of how this occurred in the Quatro Estações and Rainha de Maio cultivars cultivated in the organic system were distinct. Rainha de Maio began with slow but higher germination and had small increments thereafter, while the Quatro Estações cultivar started with a lower average, but at a faster rate, eventually remained stationary. In general, the process stabilized around the tenth day (Figure 2) for all the varieties, regardless of the cultivation system applied.

Salad rocket seeds did not differ in the percentage of germination ( $76.80 \leq \mathrm{G} \leq 77.20 \%$; Table 3). With a maximum decrease of $23.2 \%$ when compared to the conventional system, organic seeds presented a decrease of only $16.2 \%$. These seeds were stored for 13.09 years, i.e., they were the oldest seeds to be analyzed in this study, and yet they were superior. For salad rocket seeds, although the conventional system resulted in more uniform germination (mean germination time of 1.72 days), the organic system was faster $(\mathrm{CVt}=26.23 \%$; Table 3$)$.

This result was discrepant between cultivation systems; once the organic one resulted in a dispersion around the mean germination time of $88.61 \%$, while for the conventional one, it was $26.23 \%$. Through the germination frequency, it became evident that the processes in both systems were similar, as they began with a great peak (Figure 3). The organic system presented a peculiar frequency distribution, in which higher frequencies were observed in the initial germination time until the eighth day (Figure 3b); therefore, it resulted in the variability around the mean germination time $\left(\mathrm{CV}_{t}=88.61 \%\right.$, Table 3). In addition, the relative frequency chart ratified the fact that there was no difference from the beginning of the germination process (Figure 3), which could be verified in all observations (seen through the standard deviation equal to 0) (Table 3). This unique response to initial time has not been observed in the final time, in which organic seeds took longer to germinate overall.

Organic salad rocket seeds germinated faster than the conventional speed of 0.60 day $^{-1}$. As a result of the increased speed and not of capacity (germination), the germination rate was also higher, with 18.37 rootlet protrusions a day. The uncertainty verified in the germination process was lower in the conventional system $(Z=0.34)$, which indicates a greater synchronization index. According to another mathematical calculation, the synchronization index ratified this behavior and showed a greater germination overlap in a same period $(Z=0.87)$. Germination began with distinct values, close to $70 \%$ for conventional salad rocket seeds and 55\% for the organic ones (Figure 4). A rapid increment occurred in organic seeds, which helped them reach the percentages of conventional seeds, and from the eighth day onwards, the process stabilized for both systems (Figure 4).

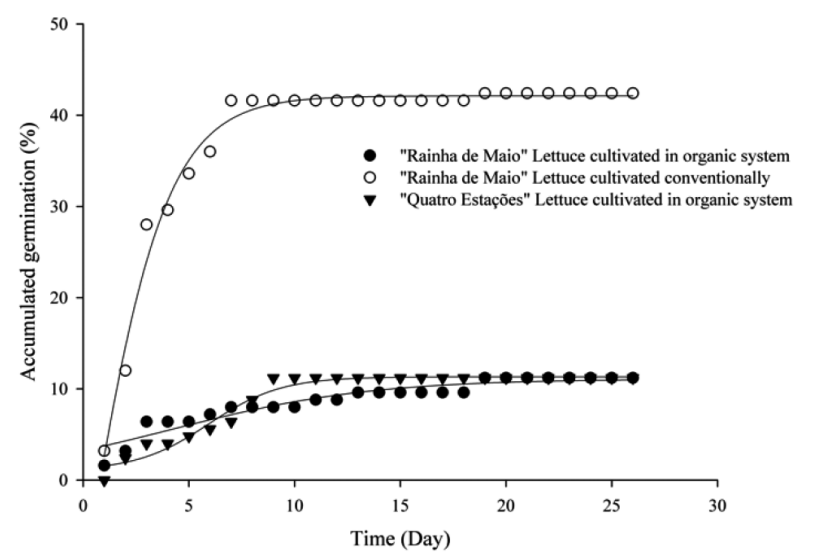

$$
\begin{gathered}
Y_{\text {(rainha org.) }}=1.57+9.85\left(1-10^{(0.13 x)}\right) \\
R^{2}=93.83 \% \\
Y_{\text {(rainha conv.) }}=-18.89+61.19\left(1-10^{(0.42 x)}\right) \\
R^{2}=98.26 \% \\
Y_{\text {(quatro estaçōes org.) }}=-3.06+14.8\left(1-10^{(0.2 x)}\right) \\
R^{2}=93.65 \%
\end{gathered}
$$

Figure 2. Accumulated cypselae germination of lettuce cultivars (Lactuca sativa L.) after storage. 
(a)

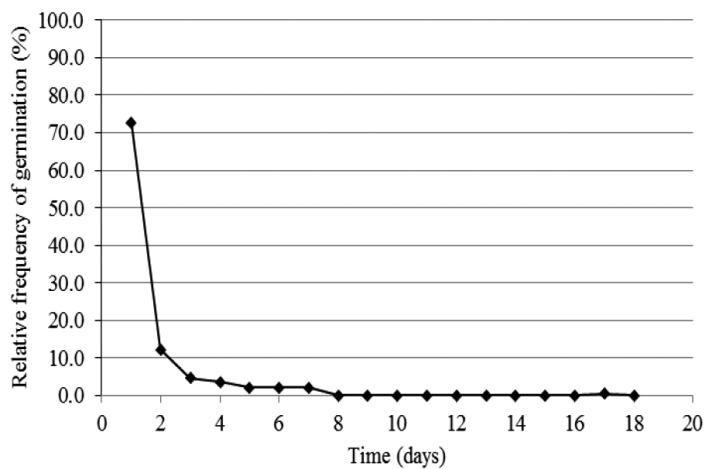

(b)

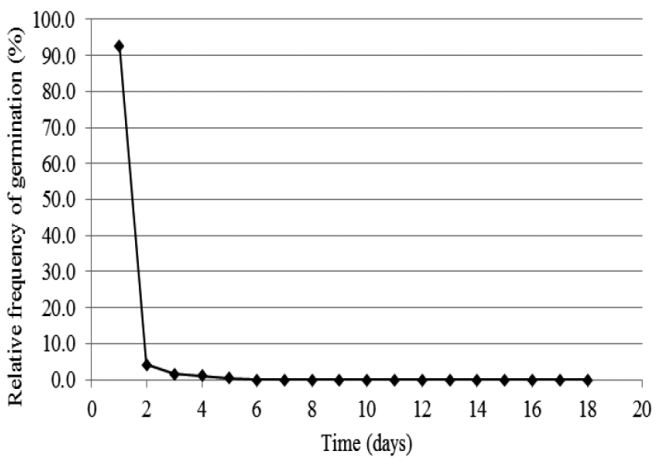

Figure 3. Stored seeds relative frequency of germination of "Cultivada" salad rocket (Eruca sativa L.) cultivated in a) conventional system and b) organic system.

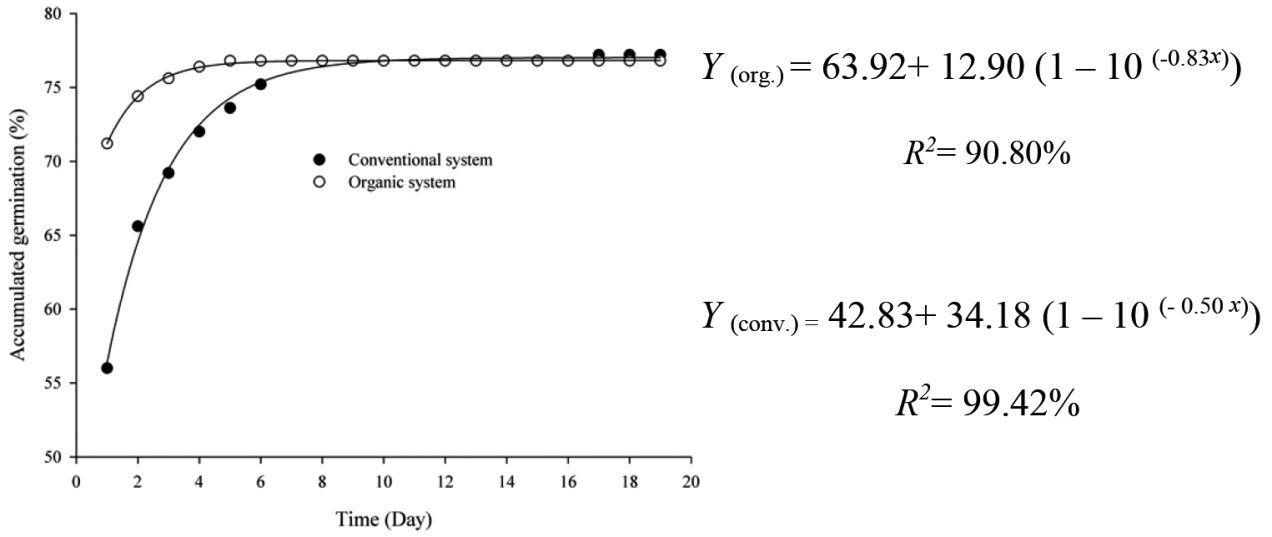

Figure 4. Stored seeds accumulated germination of "Cultivada" salad rocket (Eruca sativa L.).

Lettuce cypselae and salad rocket seeds remained viable for storage periods exceeding ten and nine years, respectively. Maintaining viability for long periods is especially interesting for germplasm banks and subsequent breeding programs. Both temperature and relative humidity in storage as well as water content are some of the factors that should be monitored. The period of seed viability depends on both genetic traits and environmental effects during the phases of development, collection, processing, and storage (Santana and Carvalho, 2006; Gris et al., 2010). The duality of the genetic factor and cultivation system (conventional and organic) was observed in this study. The percentage of germination of anhydrobiotic (= orthodox) cypselae of the cultivar "Quatro Estações" in the conventional system reduced to zero after 10 years (Table 3 ), which did not occur for "Rainha de Maio." Thus, there are genes that can be addressed to improve the storage characteristics in lettuce cypselae. Even though it is not the focus of lettuce genetic improvement, better germination characteristics may be advantageous in the cultivar's portfolio. Similarly, the available evidence suggests that there are differences between progenies for germination characteristics for low-germination carrot seeds. Moreover, the high rates of heritability and genetic variability suggested that conventional breeding combined with methods of selection based on the index theory can be applied to improve the seeds' physiological quality (Vieira et al., 2005).

The Cultivada salad rocket seeds stored for 9.92 (conventional) and 13.09 (organic) years succeeded in better maintaining germination (76.80; 77.20\% and respectively) in comparison with the two cultivars of lettuce studied and also concerning other studies, such as carrot seeds (Ortiz et al. 2014). These researchers found that germination was 
only $38 \%$ per batch after being stored for 10 years, which suggests that storage of carrot seeds from the Londrina cultivar must not exceed 10 years since its germination percentage did not reach the minimum standard, which is $65 \%$. In short, ensuring quality in stored seeds should also account for differences between genotypes (Lee et al., 2002), both in seed production method and genetics.

In lettuce, storage boosts the activity of the esterase enzymes in cypselae (Diniz et al., 2009), leading to faster ester hydrolysis, which is linked to the lipid metabolism as well as the membranes' degenerative process. The same phenomenon could be verified with the endo- $\beta$-mannanase throughout storage (Diniz et al., 2009). This enzyme is responsible for the degradation of reserve mannans present in lettuce cypselae. Thus, the evidence suggests that the Quatro Estações cultivar, as a result of null germination, presents a deficiency in these enzymes, which are essential for the embryo's nourishment. Therefore, the seeds must be stored for periods below the one tested in this study. It is crucial to stress that null germination only occurred in the conventional system, that is, the one with low organic matter levels in the soil. Stabilized soils with proper organic carbon balance may have a population of interesting bacteria, such as growth-promoting ones. These bacteria aid in the biological fixation of nitrogen, solubilize phosphate and zinc, produce siderophores, auxins, gibberellins, and cytokinin (Saravanan et al., 2007; Santi et al., 2013; Estrada et al., 2013). The exogenous supply of plant hormones of bacterial origin may cause the difference in the response as far as the germination percentage and the germination time variation coefficient in both systems are concerned, specifically by supplementing the deficiency of hormones. Gibberellin deficiency has been known to reduce the activity of the endo- $\beta$ -mannanase enzyme in seeds (Diniz et al., 2009), which consequently reduces vigor.

The synchronicity, evaluated through uncertainty, and the mean germination time observed in both varieties and cultivation systems were close with those observed by Bufalo et al. (2012). Similarly, the varieties' average germination times, ranging from 3.9 to 6.4 days, were consistent to those seen by Kikuti and Marcos Filho (2012) (Vanda and Vera cultivar), lettuce seeds that had been freshly harvested or stored for up to a year. However, they were higher than those observed by Carnelossi et al. (1995) in the Maioba cultivar and similar to those of the Moreninha de
Uberlândia cultivar. The dynamics of the cypselae germination in the two varieties of lettuce observed by Carnelossi et al. (1995) took less time to stabilize (3 days) than those observed in this study (up to 5 days; Figure 3). However, the author worked exclusively with 3-month-old cypselae, whereas, they had been stored for several years. Thus, the time dynamics are conservative of the genotype and little influenced by external factors. The germination process has been known to be species-specific, as if it followed a biological clock, with its starting and ending times set, regardless of the extra factors (Ribeiro-Oliveira et al., 2013). This is ratified by the relative frequency polygons of Salad rocket seeds (Figure 2) and the Rainha de Maio cypselae (Figure 1a). The graph of the former just differed regarding the capacity. It should be noted that the peak of the latter at 18 days after planting while being small in the conventional system reflects the strategy of the species in preserving its germination dynamics. Similar conservative behavior was observed in all germination relative frequency graphs in cypselae which were subjected to stratification $\left(5^{\circ} \mathrm{C}\right)$ for different periods, light conditions, and temperatures for germination, which tended to present a unimodal fashion, with negative asymmetry in the first two days (Bufalo et al., 2012).

The enzymatic deficiency may be one of the causes of particularity in the germination process in each cultivar, but it is not the only cause. Some studies report that properly fertilized plants are more likely to produce a larger amount of seeds, alongside improved quality, since they resist adversity better. However, the relation between the seed's cultivation system and physiological potential has not been consistently observed. This is partly because plants developed the ability to adjust the seed production to the resources available (Delouche, 1980); if there is low soil fertility there will be a reduction in the amount of seeds produced before there is a decrease in seed quality. However, studies such as Zucareli et al. (2006) suggest that the effect of plant nutrition on the quality of the seed can be observed only after a period of storage. In this sense, newly harvested lettuce cypselae from plants fertilized with increasing doses of $\mathrm{P}_{2} \mathrm{O}_{5}$ showed similar vigor. However, when stored for 25 months, the percentage of seedlings increased linearly in the first count, and germination and the rate of Maguire according to the doses of $\mathrm{P}_{2} \mathrm{O}_{5}$ (Kano et al., 2006).

In general, conventionally-grown salad rocket seeds showed better results, despite no difference 
in germination capacity. In spite of the insufficient research on salad rocket concerning the impact of cultivation systems on seed production, the conclusions drawn from results of other oleraceous crops converge. These studies sought to verify the influence of organic and conventional production systems on the physiological potential of coriander seeds. They conclude that, in general, the initial quality of the seeds was not influenced by cultivation systems since the difference in quality among the lots studied was small (Silva et al., 2012). However, Casaroli et al. (2006) found that the greatest physiological potential was observed in conventionally-grown seeds for the pumpkin seeds of the cultivar Menina Brasileira.

\section{Conclusion}

Lettuce Cypselae tolerates storage for extended periods (more than ten years) while retaining the viability and germination pattern over time. However, the answer is strictly linked with the genotype. The cypselae of the Rainha de Maio cultivar were more suitable when produced in the conventional system, whereas for the Quatro Estações cultivar, only the organic system proved suitable. Salad rocket seeds remain viable for long periods (more than nine years) with more than $70 \%$ germination, regardless of the cultivation system. However, the conventionally-grown ones show faster, more uniform, and synchronous germination.

\section{Literature Cited}

Bufalo, J.; Amaro, A.C.E.; Araújo, H.S.; Corsato, J.M.; Ono, E.O.; Ferreira, G.; Rodrigues, J.D.

2012. Períodos de estratificacáo na germinacáo de sementes de alface (Lactuca sativa L.) sob diferentes condicoes de luz e temperatura. Semina: Ciénc. Agrár., 33(3): 931-940.

Cardoso, A.I.I.; Ferreira, K.P.; Vieira Júnior, R.M.; Alcarde C. 2011. Alteracoes em propriedades do solo adubado com composto orgánico e efeito na qualidade das sementes de alface. Hortic. Bras., 29: 594-599.

Carnelossi, M.A.G.; Lamounier, L.; Ranal, M.A.

1995. Efeito da luz, hipoclorito de sódio, escarificacáo e estratificacáo na germinacáo de sementes de alface (Lactuca sativa L.), cv. Maioba e Moreninha-de-Uberlándia. Pesq. agropec. bras., 30(6): 779-787.

Casaroli, D.; Garcia, D.C.; Muniz, M.F.B.; Menezes, N.L. 2006. Qualidade sanitária e fisiológica de sementes de abóbora variedade Menina Brasileira. Fitopatol. bras. 31(2): 158-163.

Delouche, J.C.

1980. Environmental effects on seed development and seed quality. Hortscience, 15(6): 775-780.

Dias, M.A.; Guimaraes, G.A.M.; Pilon, A.M.; Muzzi, E.M. 2015. Diagnóstico da producáo de sementes orgánicas: estudo de caso do "Grupo Seriema" em Laranja da Terra, ES. Revista de Extensáo e Estudos Rurais, 4(1): 45-55.

Diniz, K.A.; Oliveira, J.A.; Silva, P.A.; Guimaráes, R.M.; de

Carvalho, M.L.M.

2009. Qualidade de sementes de alface enriquecidas com micronutrientes e reguladores de crescimento durante o armazenamento. Rev. bras. Sementes, 31(1): 228-238.

Estrada, G.A.; Baldani, V.L.D.; Oliveira, D.M., Urquiaga, S.; Baldani, J.I.

2013. Selection of phosphate-solubilizing diazotrophic Herbaspirillum and Burkholderia strains and their effect on rice crop yield and nutrient uptake. Plant Soil, 369(1): 115-129.

Gris, C.F.; Von Pinho, E.V.R.; Andrade, T.; Baldoni, A.; Carvalho, M.L.M.

2010. Qualidade fisiológica e teor de lignina no tegumento de sementes de soja convencional e transgénica RR submetidas a diferentes épocas de colheita. Ciénc. Agrotec., 34(2): 374-381.
Kano, C.; Cardoso, A.I.I.; Higuti, A.R.O., Villas Boas, R.L. 2006. Doses de potássio na producáo e qualidade de sementes de alface. Hortic Bras., 24(3): 356-359.

Kikuti, A.L.P.; Marcos Filho, J.

2012. Testes de vigor em sementes de alface. Hortic. Bras., 30(1), 44-50.

MAPA.

2011. Sementes e Mudas Orgánicas Instrucjío Normativa N 38 , 02 de agosto de 2011. Ministério da Agricultura, Pecuária e Abastecimento. Available: http://www.agricultura.gov.br/ assuntos/sustentabilidade/organicos/legislacao/portugues/ instrucao-normativa-no-38-de-02-de-agosto-de-2011-sementese-mudas-organicas.pdf/view Cconsulted: 1/Feb/2018. MAPA.

2013. Plano nacional de agroecologia e producáo orgánica - PLANAPO. Ministério do Desenvolvimento Agrário. Available: http://portal.mda.gov.br/portal/institucional/ planapo; consulted: 1/Feb/2018.

Nascimento, W.M.; Vidal, M.C.; Resende, F.V.

2012. Producáo de sementes de hortalicas em sistema orgánico. XII Curso sobre tecnologia de producáo de sementes de hortalicas, Mossoró- 22 a 24/oct/2012.

Ortiz, T.A.; Lone, A.B.; Unemoto, L.K.; Athanázio, J.K.;

Takahashi, L.S.A.

2014. Metodologias para avaliacáo da qualidade fisiológica de lotes de sementes de cenoura variedade Londrina armazenados por até dez anos. Biosci. J., 30(1): 330-337.

Ranal, M.A.; Santana, D.G.

2006. How and why to measure the germination process?

Rev. Bras. Bot., 29(1): 1-11.

Ribeiro-Oliveira, J.P.; Ranal, M.A.; Santana, D.G.

2013. A amplitude amostral interfere nas medidas de germinacáo de Bowdichia virgilioides Kunth?. Ci. Fl., 23(4): 623-634.

Santana, A.M.S.; Carvalho, R.I.N.

2006. Viabilidade e capacidade de armazenamento de sementes de carqueja em tres municipios no Paraná. Scientia Agraria, 7(1): 15-20.

Santi, C.; Bogusz, D.; Franche, C.

2013. Biological nitrogen fixation in non-legume plants. Ann. Bot. (Oxford), 111(5): 743-767. 
Saravanan, V.S.; Madhaiyan, M.; Thangaraju, M.

2007. Solubilization of zinc compounds by the diazotrophic, plant growth promoting bacterium Gluconacetobacter diazotrophicus. Chemosphere, 66(9): 1794-1798.

Silva, M.A.D.; Coelho Júnior, L.F.; Santos, A.P.

2012. Vigor de sementes de coentro (Coriandrum sativum L.) provenientes de sistemas orgánico e convencional. Rev. Bras. Plantas Med., 14(1): 192-196.
Vieira, J.V.; Cruz, C.D.; Nascimento, W.N.; Miranda, J.E.C. 2005. Selecáo de progenies de meio-irmáos de cenoura baseada em características de sementes. Hortic. Bras. 23(1): 44-47. Zucareli, C.; Ramos, J.; Edison, U.; Barreiro, A.P.; Nakagawa, J.; Cavariani, C.

2006. Adubacáo fosfatada, componentes de producáo, produtividade e qualidade fisiológica em sementes de feijáo. Rev. Bras. Sementes, 28(1): 9-15. 